\title{
The theory of international business: the role of economic models
}

Article

Accepted Version

Casson, M. (2018) The theory of international business: the role of economic models. Management International Review, 58 (3). pp. 363-387. ISSN 1861-8901 doi:

https://doi.org/10.1007/s11575-018-0342-6 Available at https://centaur.reading.ac.uk/75720/

It is advisable to refer to the publisher's version if you intend to cite from the work. See Guidance on citing.

To link to this article DOI: http://dx.doi.org/10.1007/s11575-018-0342-6

Publisher: Gabler Verlag

All outputs in CentAUR are protected by Intellectual Property Rights law, including copyright law. Copyright and IPR is retained by the creators or other copyright holders. Terms and conditions for use of this material are defined in the End User Agreement.

\section{www.reading.ac.uk/centaur}

\section{CentAUR}

Central Archive at the University of Reading

Reading's research outputs online 
The Theory of International Business: The Role of Economic Models

\author{
Mark Casson
}

Keywords: INTERNATIONAL BUSINESS; MULTINATIONAL ENTERPRISE;

INTERNALISATION; THEORY; SYSTEM; MODULARITY; DECISION TREE

Word count (excluding abstract): 10,234

Address for correspondence:

Mark Casson

Department of Economics

University of Reading

PO Box 218

Reading RG6 6AH, UK

Tel: (44) (0) 1491681483

E-mail: $\underline{\text { m.c.casson@ @eading.ac.uk }}$

Date: 30 July 2017 


\begin{abstract}
This paper reviews the scope for economic modelling in international business. It argues for a multi-level theory based on classical internalisation theory. The theory extends the 'systems approach' to the multinational enterprise in which modular activities, such as production, marketing and $R \& D$, are linked by flows of semiprocessed products and proprietary knowledge. It is shown how this theory can be extended from the firm level to the industry level in order to analyse inter-firm cooperation and rivalry. The theory can be extended to higher levels (e.g. the global economy) and lower levels (e.g. personal relationships within plants and offices).
\end{abstract}

(99 words) 


\section{The Theory of International Business: The Role of Economic Models}

\section{Introduction}

This paper reviews the scope for economic modelling in international business (IB) theory. Economic modelling was commonplace in the 1970s, became unusual in the 1990 s, and was controversial by 2000 . There are eminent IB scholars today who deny the usefulness of formal economic models in IB.

This is odd. Economic theory addresses existential issues in IB. Why do firms become multinational? Why are some firms multinational and others not? Why did the number and the size of multinationals (MNEs) increase in the 1950s? Why did 'new forms' of MNE emerge in the 1980s and 1990s? Economic theory provides a set of general principles that addresses these issues.

MNEs are clearly economic in terms of the functions they perform, e.g. production, investment and trade. They employ labour, borrow capital and have shareholders who bear business risks. They are not purely economic, of course. Their managers and workers socialise amongst themselves. They are multi-cultural organisations, but they are not the only organisations of this type. The United Nations, the European Union and other inter-governmental organisations are multi-cultural too. No-one argues that political organisations should be analysed without reference to politics, so why should MNEs be analysed without reference to economics? MNEs may well be multicultural, but that is not their defining characteristic.

Economic analysis has been crowded out of leading IB journals by studies of crosscultural organisation. These studies examine issues that are not specific to MNEs; they do not explain why MNEs exist, which markets they serve and where they produce. They typically ignore the fact that MNEs are profit-driven, subject to competitive pressures, and must be efficient in order to survive.

Two main factors explain the shift away from economics: economic theory is perceived as highly technical and of little practical relevance, while business strategy is seen as offering a more relevant non-technical substitute.

Critics of economics claim that economic theory has become a mere collection of mathematical models whose assumptions are patently absurd. Mathematics is employed, it is said, not for its practical utility, but to create a pseudo-scientific image and to confer spurious authority. Excessive reliance on mathematics, the critics claim, renders economic theory unintelligible to students and irrelevant to practising managers.

Distaste for economics in general, and mathematics in particular, has led to low citations of economic papers. Some journal editors avoid publishing economics papers because impact factors, and hence rankings, may be lowered; this in turn discourages economic research in IB.

The 'other side of the coin' is the rise of business strategy. It is widely believed that the most important aspects of economic theory have been incorporated into theories of business strategy. There is an element of truth in this. Porter's (1980) seminal work 
on Competitive Strategy took the basic principles of industrial organisation theory and presented them, not from the standpoint of government regulation, but from a boardroom perspective. There is a problem, however. Porter over-simplified the economic theory of industrial organisation. He dropped the industry perspective, which was fundamental to the theory, and replaced it with the firm perspective. But he failed to alert his readers to what he had done. He coined new terms, such as 'value chain', for existing concepts, such multi-stage production and (more controversially) substituted 'competitive advantage' for monopoly power. By inventing new jargon, and failing to acknowledge some of his sources, Porter cut off his readers from the intellectual tradition on which he himself relied.

In the 1980s a new generation of scholars, teaching strategy in business schools, began to theorise using Porter's concepts, unaware that his over-simplified framework was inadequate for rigorous theory development. The most obvious symptom of the failure of the strategy literature is the confusion that now prevails on theoretical issues. Over-simplification has destroyed much of the legacy of earlier theory.

If IB theory is to progress, future developments need to be based on more secure foundations than strategy. It is necessary to go 'back to basics'. This involves stripping away the superfluous concepts that have proliferated in IB theory over the past twenty years. The first step in theory development must be to recover the fundamental principles on which IB theory was originally based. This paper sets out these principles and outlines a research agenda that builds upon them.

\section{Back to basics: the role of theory}

A good way to begin is with the question 'Why is theory so important, and what distinguishes a good theory from a bad one?'. A good theory affords a unified explanation of a range of different phenomena concerning a given topic. Theory provides economy of thought. It summarises a mass of detail by postulating a simple set of relationships that fits all (or most) of the facts.

Good theory is logically consistent. It deduces multiple hypotheses from the same set of core assumptions. Good theory usually involves contingency: it explains not only what is normal, but why different outcomes emerge under different circumstances. Under conditions $A$ the outcome $X$ is observed, and under conditions $B$ outcome $Y$ is observed instead. It may be said that $A$ causes $X$, and $B$ causes $Y$, especially if $X$ and $Y$ appear after $A$ and $B$. In economic theory outcomes are typically rational responses to causal factors, i.e. $X$ is the best response to $A$ and $Y$ the best response to $B$.

Economic theory is highly contingent. Because resources are scarce, trade-offs are common, and so economic behaviour adapts as resources change. Unlike strategy, which often purports to identify the 'one best way' of doing things, economics shows that adaptation is usually the best strategy.

It is often said that a good theory is a simple theory (Morgan, 2012). But there is a trade-off. A simple theory is often unrealistic. IB is an inherently complex subject. It involves the interplay of location and ownership within a global system of production. Everything is connected to everything else in the global economy and a good theory will recognise this. Good theory clarifies the nature of these interdependencies; it does 
not just assume them away. Good theory is more realistic than simple theory; it reflects the genuine complexity of the system and clarifies the nature of the interdependencies that hold it together. Good theory is not only about simplicity, but about clarity of thinking too.

While interdependency and contingency increase the complexity of economic theory, they enhance realism and therefore explanatory power. It is better to have a single contingent theory that explains a range of phenomena with clarity than a portfolio of simple theories that each explain a different phenomenon. It is easier to understand a general theory based on a single set of assumptions than a collection of special theories based on different assumptions that cannot be reconciled with each other. This paper therefore focuses on general theories rather than specific theories of specific phenomena.

\section{Origins of modern IB theory}

\subsection{The failure of neoclassical theory}

IB theory did not emerge simply because someone thought that it would be a good idea. It emerged because orthodox theory failed. It could not account for the rise of MNEs in the post-1945 period. In particular, it could not explain the dramatic growth in the number and size of MNEs, why they were mainly headquartered in the US and why they mainly invested Europe. Furthermore, it could not explain why their investments were concentrated in technology-intensive and marketing-intensive industries.

Mainstream 'neoclassical' economists regarded foreign direct investment (FDI) simply as a form of international capital flow (McDougall, 1960, Kemp, 1971). Capital was assumed to be homogeneous, and no distinction was drawn between direct investment (giving control of resources through a majority equity stake) and indirect or portfolio investment (involving minority equity stakes and bonds).

Neoclassical theory predicted that

- at any given time there would be a net flow of investment from low-profit countries to high-profit countries;

- this flow would be transitory; it would cease once international capital stocks had adjusted so that profits rates were equalised across countries;

- since capital was homogeneous, flows would be the same irrespective of industries; and

- there would be no 'cross-hauling'; i.e. capital would only flow in one direction at the same time.

This conflicted with just about everything that was known about FDI at the time (Dunning, 1958):

- it flowed from a high-profit country ,the US, to low-profit countries in Europe;

- it was persistent and growing;

- it was industry-specific; and

- it flowed in both directions at once. 
The abject failure of neoclassical theory is summarised in Table 1. The key facts are shown in the left-hand column. The neoclassical predictions are shown in the middle column, and the predictions of modern IB theory in the right-hand column. IB theory provided a simple, direct and intuitively satisfying explanation for everything that neoclassical theory failed to explain.

\subsection{Three key questions}

The basic outline of IB theory was established over the period 1960-76. Three key questions were identified, as shown in the left-hand column of Table 2. The answers given are shown in the middle column and the type of theory from which the answers were derived appears in the right-hand column.

- Location of production. Why would US firms produce in Europe rather than the US? Answer: The post-war 'dollar shortage' made US labour expensive relative to European labour, while high-tariffs encouraged European production in order to 'jump the European tariff wall'.

- Ownership of production. Politicians were mystified by how US firms achieved higher productivity than European firms when employing European workers. Surely they must have suffered from lack of local knowledge? Explanation: US firms possessed a countervailing advantage in superior technology, labour management and/or marketing methods, which compensated for their lack of specific local knowledge.

- Internalisation advantage. Why not have the best of both worlds, by combining the general knowledge of the US firm with the local knowledge of a European firm using a license agreement in which a European firm produced the US product for the European market using US technology? Answer: There must be some obstacle to licensing which makes it more efficient to internalise the transfer of knowledge from the US to Europe within the US firm.

The first two question concerning location and ownership were addressed by the Hymer-Kindleberger (HK) theory (Hymer, 1976; Kindleberger, 1969). This theory appealed to trade theory for its explanation of location, and to monopoly theory for its explanation of the firm's advantage. The final question concerning licensing was addressed using internalisation theory, as explained below.

\section{Two approaches: eclectic theory and internalisation theory}

There were two different responses to this early success of IB theory.

- A special theory of IB was all that was required, and that had already been developed. It explained the special facts that neoclassical theory could not explain. The HK theory was perfectly sound, and internalisation was just an 'add-on'. Adding internalisation created the 'eclectic theory' (Dunning, 1977). The key facts could be explained terms of three advantages, corresponding to the three questions listed in the table; location, ownership and internalisation. It was stated, rather rashly, that these advantages together were necessary and sufficient for FDI. 
- The second response was that, since neoclassical economics claimed to be a general theory, but could not explain IB, it must be fundamentally flawed, and therefore needed to be replaced. A new general theory was required to restore the credibility of economics. It would be a general theory of the firm in space; the MNE would emerge quite naturally under specific conditions, so IB would figure as a special case (Buckley and Casson, 1976).

Advocates of the first approach regarded the second approach as extravagant, and much of its content superfluous. Advocates of the second approach claimed that they could achieve much more than simply explaining some specific facts: their approach provided a general framework within which many different types of firm, and many different forms of firm behaviour, could be understood. By embedding specific explanations within a wider framework, greater analytical clarity would be achieved. This second approach led to classic internalisation theory.

\section{Classic internalisation theory}

\subsection{The multi-plant firm}

Neoclassical theory confused two fundamental concepts: the plant and the firm. Internalisation theory, on the other hand, drew a key distinction between them. A plant was a physical facility; it could be a factory, R\&D laboratory, warehouse, office or shop. The firm, by contrast, was an institution. It owned the product produced in its facilities. The firm was a legal instrument through which shareholders combined their capitals to produce an output that was sold for profit. The firm was a fictional person, recognised in law, that acted as a nexus of contracts between workers, shareholders, suppliers and customers. It added value by intermediating between them.

Neoclassical economics implicitly assumed that firms were single plant firms, and therefore operated in a single country. This reflected reality at the end of the nineteenth century, at the time when the theory was developed. But even then multiplant firms were becoming more common, although most were only multi-regional (e.g. retail chain stores).

A multi-plant firm operates several plants in different locations, and if the plants are in different countries then the firm becomes an MNE. National borders are often arbitrary; e.g. drawn up to consolidate territory gained or lost through war. Internalisation theorists believed that once the economic logic of the multi-plant firm was established it would be easy to account for the MNE on the basis of the irrationality of national borders. Multi-plant firms would naturally be multinational if the 'costs of doing business abroad' (or the 'liability of foreignness' in modern terminology) were not too high.

\subsection{The legacy of Ronald Coase}

The development of internalisation theory was inspired by the work of Ronald Coase (1937), who was in turn inspired by the work of his mentor Lionel Robbins (Casson, 2014). Coase's analysis of 'the nature of the firm' was embedded within a more general question of what determines the balance between 'planning' and 'prices' in 
the allocation of resources within a national economy. This was a topic of intense ideological debate in the 1930s.

Coase noted that the state is not the only institution that undertakes planning; firms also plan. But unlike the state, which asserts its authority to plan, firms only plan by consent; the shareholders must agree to invest, the workers must agree to be employed, and the customers must agree to buy the product. Furthermore, the state must be willing to recognise firms as legal entities.

Firms plan by consent, Coase argues, because markets are imperfect, and so under certain circumstances it pays to replace them with firms. The more imperfect are markets, the greater the benefits of firms. But planning systems are imperfect too, so the boundaries of a firm are set where the marginal benefit of planning (i.e. internalisation) is equal to the marginal benefit of using prices (i.e. arm's length contracts).

\subsection{Modular systems}

Internalisation theorists applied this idea to inter-plant coordination. They took a modular view of production. Production may involve a set of different activities, each carried out in a different plant. Modularisation may be vertical, with upstream production feeding into downstream production, or horizontal, where different plants perform the same activity at different locations.

Vertical modularisation takes two main forms. The first involves a flow of semiprocessed product through a multi-stage production system and the second involves a flow of knowledge between R\&D and production. The first flow typically involves raw materials and components, while knowledge flow may involve only documents.

Knowledge is a public good; it can be shared by different plants. It is usually more economic for two plants to share the same knowledge rather than to independently generate the same knowledge for themselves.

- Where different plants in different locations share the same knowledge vertical modularisation involving $\mathrm{R} \& \mathrm{D}$ is linked to horizontal modularisation involving production.

- Where the knowledge is shared by different plants at different stages of production two types of vertical modularisation are involved: one involves the flow of knowledge to the plants and the other involves the flow of semiprocessed product between the plants.

Each form of modularisation has its own coordination requirements. Multi-plant firms arise when the internalisation of coordination brings different plants under common ownership and control. Internalisation theory embraces all forms of modularisation. Some writers, however, emphasise vertical modularisation involving knowledge to the exclusion of everything else; this over-simplifies the theory and weakens its explanatory power.

\subsection{Specific applications of Coase: theories of vertical and horizontal integration.}

The strength of Coase's work is its high level of generality. It has two main 
weaknesses, however.

- Lack of practical applications. Coase's main example of internalisation involves intra-plant coordination involving teams; the productivity of each team member depends on the productivity of others, and so the employer directs each worker while they perform their tasks (see also Alchian and Demsetz, 1972). There is no analysis of inter-plant coordination, as discussed above. There is certainly no discussion of the internalisation of knowledge; indeed, Coase specifically claims that knowledge cannot be appropriated, and that attempts by firms to uphold intellectual property are futile.

- Vagueness about the nature of market costs. Coase refers mainly to the costs of 'discovering prices'. Today it is recognised that markets incur several different types of cost:

- Search costs: identifying potential trading partners and making contact with them;

- Specification costs: specifying product characteristics;

- Negotiation costs: bargaining over price and other terms of contract;

- Administrative costs: coordinating time and place of delivery; and

- Enforcement costs: Deterring default on product quality or payment with the threat of prosecution or reprisal.

Coase seems to refer to search costs, while today most emphasis is placed on enforcement costs.

\subsection{Vertical integration in production}

For practical insights into internalisation it is necessary to consult the literature on vertical and horizontal integration.

The theory of vertical integration focuses on intermediate product flow between upstream and downstream plants. 'Integrated' plants have a common owner and so internalise the intermediate product market between them. Table 3 summarises key literature, some of which pre-dates Coase.

A popular explanation for vertical integration in manufacturing was the potential to rationalise inventory; a point later refined by Arrow (1975), who identified missing contingent forward markets as a motive for internalisation. Another explanation emphasised that monopoly at any stage of production distorts relative prices at adjacent stages unless the distortion is removed by internalisation (Warren-Boulton, 1978). Williamson $(1975 ; 1985)$ offered two explanations for vertical integration; firstly that it reduces the costs of repeated contracting, and secondly (following Klein, Crawford and Alchian, 1978) that it mitigated bargaining problems when upstream and downstream plants were locked into each other (e.g. by co-location or technological complementarity). IB theory added yet another factor: improved quality control; quality control is easier when the downstream firm owns its own source of supply (Casson, 1987).

Today vertical integration plays a prominent role in analysing resource-seeking MNEs that integrate backwards into overseas mining or agriculture. 


\subsection{Horizontal integration in production}

Horizontal integration occurs where two or more plants at the same stage of production are owned by the same firm; it is key to the standard analysis of the market-seeking MNE. Early literature associated horizontal integration with monopoly power If a customer typically visits two different stores in two different towns and buys from the cheapest, and a chain store then takes over the independents or drives them out of business, the customer's choice is limited and competition is suppressed. Monopoly power drives up the price and rewards the chain store with monopoly profit.

The arm's length equivalent of horizontal integration is the cartel (Casson, 1985). A cartel is an agreement between firms to maintain prices above their competitive level. International cartels in basic commodities were common in the inter-war period (e.g. in oil, chemicals and metals). Cartel agreements are difficult to enforce, however, because covert price-cutting is easy. Enforcement is particularly difficult when cartels are opposed by governments, because they cannot then be enforced by law. Government support was forthcoming in the inter-war period because, with overcapacity in basic industries, international competition damaged the profits of 'national champion' firms, but post-war US hegemony led to cartels becoming illegal.

\subsection{Vertical and horizontal integration applied to knowledge}

The introduction of proprietary knowledge was a key innovation of modern IB theory. (Hymer, 1976; Buckley and Casson, 1976). Knowledge encompasses technology, brands, and other kinds of specialised know-how. In neoclassical theory knowledge was usually assumed to be a free good, equally accessible to all at zero cost. In IB theory knowledge is a public good (see above), but it is not a free good.

In neoclassical theory the stock of knowledge was usually taken as given. Little attention was paid to the incentive to produce it. In IB theory, however, knowledge production plays a central role. The focus is on privately-funded $R \& D$ undertaken by firms.

R\&D incurs large sunk costs which must be recovered from subsequent profits. Monopoly power is the key to profit. Imitation creates competition, undermining profits and so deterring R\&D. Patents and other intellectual property rights (IPR) are crucial in appropriating profit, but IPR can be costly to enforce.

Secrecy is an alternative to patenting when IPR is weak. Secrecy favours internalisation because of the 'buyer uncertainty' problem (Vaitsos, 1974, Casson, 1979). A potential licensee may be unsure about the quality of the secrets they are offered; they could be unreliable or they could be things that they already know. This a variant of the quality assurance problem encountered in ordinary commodity markets (see above).

Where different licensees are used in different countries, protecting monopoly profits requires a licensee's cartel. If the final product is cheap to transport then licensees can easily invade each other territories, dissipating monopoly profits though competition 
(Casson, 1985). The greater the problems of organising a licensee's cartel, the greater are the advantages of internalising all production.

The same knowledge may also be used at different stages of production. If two adjacent stages of production draw upon the same source of R\&D then internalisation of knowledge at each stage leads automatically to vertical integration in production. This applies whether or not the vertical integration has an international dimension. This point was overlooked in early statements of Williamson's (1975) influential theory of vertical integration. A great deal of ingenuity has gone into contriving explanations of domestic vertical integration in terms of opportunism and hostagetaking when a simple explanation based on shared use of the same proprietary knowledge would have been more convincing.

\subsection{Origins of classic internalisation theory: summary}

Classic internalisation theory is a reconstruction of neoclassical theory which rejects several key assumptions of the theory. Two of the rejected assumptions are fundamental:

- Markets work perfectly

- Knowledge is free to all

Two others were implicit assumptions that slipped in unchallenged:

- Each firm owns just a single plant

- FDI involves a flow of homogeneous capital

These assumptions were replaced by alternatives that are more relevant and realistic. Simply dropping objectionable assumptions and not replacing them would weaken the explanatory power of the theory. The new assumptions are:

- Markets are costly; these costs depend on product characteristics and other observable factors.

- Knowledge is often proprietary.

- The multi-plant firm represents the general type of firm and the single-plant firm of neoclassical theory is just a special case where the number of plants is one.

- FDI involves a flow of heterogeneous knowledge. Direct investment confers control of this knowledge.

In classic internalisation theory:

- Individuals are rational, though not perfectly informed. They seek out opportunities for mutual benefit whenever possible. Where competition is intense the outcome of negotiations approximates to a perfect market outcome but in other cases it does not. Monopoly outcomes are common and, when there is reliance on privately-funded $R \& D$, they may even be desirable.

- While the single plant firms may be the statistical norm, out-numbering other types of plant, the multi-plant firm represents the general case. The MNE is an important special case of the multi-plant firm. 
- Knowledge is more important than capital. Knowledge is fundamentally heterogeneous, unlike financial capital, such as bonds, which are relatively homogeneous. This means that every firm exploiting proprietary knowledge is different from every other firm that does the same and needs to be treated as such.

Some assumptions of neoclassical theory are retained by classical internalisation theory. The most important of these is profit-maximisation. Contrary to popular opinion, profit-maximisation does not imply selfishness. When shareholders finance a firm they share a common purpose to make as much profit as possible subject to the law. Their social and ethical concerns are reflected in the way they choose to spend their share of the profits, and the way they vote on government policies to regulate firms. People with a conscience (e.g. virtuous pensioners) can rightfully own shares in profit-maximising firms that follow laws designed to protect the public interest. In a competitive economy firms that fail to maximise profit are unlikely to survive and so any noble aims they profess that are at variance with profit will not be realised.

\section{The systems view}

\subsection{Linkages between production, marketing and $R \& D$}

The analysis of vertical and horizontal integration involving $R \& D$ and production is illustrated schematically in Figure 1 (see Buckley and Casson, 1998a, 1998b). An R\&D laboratory (identified by a triangle) develops knowledge that is embodied in an innovative product supplied to customers in two different countries. Local marketing and distribution is identified as a modular downstream activity, which takes wholesale product as an input from upstream production and passes it on to final consumers. Both production and marketing are represented by boxes; product flow is represented by black lines, and knowledge flow by grey lines. National boundaries are indicated by thin black lines; R\&D can be located in either country.

R\&D and production can be located in either country. Marketing and distribution have to be located close to the market however. There are thus $2 \times 2 \times 2=8$ location strategies (two for R\&D location, two for production for country 1 and two for production for country 2). Under certain circumstances the number of options can be reduced. If cross-hauling the product is inefficient, for example, only three production options need to be considered: producing locally in each country, and exporting from either country. If economies of scale are significant it may be inefficient to replicate production in both countries, and then only two production locations options would be viable.

Each linkage can be internal or external, apart from the link to the final customer, which is always external. For each location configuration, knowledge flow can be internal or external, with separate decisions made for production and marketing. If both production and marketing are internalised then product flow is internalised as well. If one is internalised and the other is not then product flow is external. With production internalised, franchising occurs, while with marketing internalised subcontracting occurs. If neither production nor marketing is internalised then the knowledge is licensed. It may be licensed to a single firm that integrates them both, or out-sourced to different firms, one of which is a subcontractor and the other a franchisee; this resembles the 'putting out' system commonly encountered in the 
textile industry and in other multi-stage production systems. Altogether, therefore, there are five main ownership options that need to be considered for each market configuration. In principle separate decisions can be made for each market. There are thus $5 \times 5=25$ distinct ownership options for production and marketing. With 8 location options there are $8 \times 25=200$ options need to be considered altogether.

\subsection{Simple internalisation theory as a special case of the systems view}

In simple expositions of internalisation theory only three configurations are considered, namely exporting, licensing and FDI. So how are 200 options reduced to three?

- The location of R\&D is fixed; this halves the options to 100. By convention $\mathrm{R} \& \mathrm{D}$ is located in 'home' country which is country 1

- The focus is on the 'foreign' market only (country 2). The 'home' country market (country 1) is served by internal local production. This reduces the locations of production options to two: export to country 2 from country 1 or produce in country 2 . Ownership choice exists only for the foreign market; this reduces the ownership options to five, leaving $5 \times 2=10$ options altogether

- In the foreign market the internalisation decision for marketing is the same as that for production; this reduces the number of ownership options to three. The total number of options is thereby reduced to six.

- If production and marketing are both out-sourced they are licensed to an integrated licensee; this reduces the number of options to four

- Exports from the home country to the foreign country are produced in a wholly-owned plant; this reduces the number of options to three.

To appreciate the limitations of simplified versions of the theory, it is important to recognise that simplification eliminates certain issues by pre-determining the relevant decisions.

- The first restriction assumes away the issue of R\&D location.

- The second assumes away off-shoring of production for the local market. Licensing production for the home market is also ruled out.

- The third rules out subcontracting and franchising, leaving licensing as the only alternative to internalisation.

- The fourth assumes that licensing involves just a single integrated licensee that undertakes both production and marketing

- The fifth assumes that a foreign licensee does not produce in the home country to serve the foreign market.

Because of these assumptions, simple versions of the theory are unable to analyse some important questions. In fact, these assumptions are quite unnecessary in order to solve the model. The full model is perfectly soluble; indeed, under certain conditions it can be solved in three simple stages. The conditions require that there are constant returns to scale in production and that local product markets are independent of each other. These conditions ensure that ownership and location decisions for each 
market depend only on the location of $R \& D$ and are independent of decisions made for other markets.

The three-stage procedure is as follows.

1. Optimise internalisation decisions for each market conditional on the location of production for that market and the location of $R \& D$. Thereby determine the minimum cost of serving each market under each location strategy given optimal internalisation decisions; this summary information is used in stage 2

2. Optimise the location of production for each market conditional on the location of $\mathrm{R} \& \mathrm{D}$. Assume that the optimal internalisation strategy is used in each market (as determined in stage 1). Thereby derive the minimum cost of serving each market conditional on R\&D location, with optimal production location and internalisation decisions. Determine the profit generated by each market conditional on the location of $\mathrm{R} \& \mathrm{D}$; this information is used in stage 3 . Hence determine whether it is profitable to serve each market.

3. Optimise the location of $R \& D$, given that, conditional on $R \& D$ location, each profitable market is served in an optimal way.

The profitability of serving individual markets depends on consumer demand as well as on cost of supply. Profit is readily calculated when demand in each market is a linear function of price, or when there is a uniform reservation price and fixed market size.

\subsection{Decision trees}

The solution described above can be illustrated using the decision tree shown in Figure 2. Each strategic option is represented by a vertical line. The tree has five levels. The decisions at any level are conditional on decisions made at a higher level. Decisions are represented by branching points in the tree where different roots diverge. These branch points are illustrated by solid circles. Each decision assumes that lower level decisions have already been optimised. To keep the tree simple, all the decisions involve binary choices; two-tiered binary decisions are equivalent to a single four-way decision, and so on.

High-level decisions concern unitary activities, where a single facility occupies a single location (in this case $\mathrm{R} \& \mathrm{D}$ ), while low-level decisions concern replicable activities, where the same activity (in this case production and marketing) may be performed at different locations. Replication is indicated by a point with a 'plus sign' inside a circle. These are the points at which decisions bi-furcate, with localised decisions at lower levels being independent of each other.

\subsection{Decentralisation of decision-making}

Decisions relating to each replicable facility depend only on decisions taken with respect to unitary facilities (R\&D). Decisions related to replicable activities can therefore be decentralised to the facilities concerned. Each market has a local manager appointed by headquarters. This manager obtains quotes for wholesale product supply from alternative producers at different locations, and compares them with 'do-it- 
yourself' internal production costs at these same locations. They also solicit bids from local licensees and franchisees, and compare these bids with the profit that could be obtained from 'do-it-yourself' local marketing. The quotes are then adjusted for differential transport costs, contractual costs and other costs incurred. The optimal market-sourcing decision is then determined by maximising the profit generated by the market.

Each local manager communicates their profit estimate to headquarters. This quote is conditional on R\&D location, since this determines the knowledge transfer costs incurred in production. Headquarters then determines the optimal location of R\&D by comparing the net profit contribution of alternative $\mathrm{R} \& \mathrm{D}$ locations, taking account of access to supply of local skills, the advantages of co-location with headquarters, and other relevant factors. Once R\&D location has been determined, the decision is communicated to local managers and they implement local arrangements.

At the appropriate stage a local manager may decide not to serve a market, or headquarters may decide not to carry out $R \& D$; there is no incentive for the firm to undertake any activity that makes a loss.

Decentralisation effects a division of labour in coordination. Different people are responsible for different stages of decision-making. Global decisions about R\&D are taken at headquarters by people with global vision, who synthesise and interpret summary information supplied by local managers from across the world. Local decisions are taken by local managers who have access to local information that headquarters staff lack. Centralisation, by contrast, requires headquarters staff to process detailed information from many locations without much knowledge of the local context from which it has been supplied.

Although the IB literature has discussed decentralisation at great length, the logical structure of decision-making revealed by decision-tree analysis is rarely mentioned. This logical structure depends on the nature of production and marketing, and in particular the strength of local market inter-dependencies and economies of scale. Other factors are important too. Decentralisation is most advantageous when information is highly localised and communication costs are high. Since communication costs increase with speed, this implies that decentralisation is favoured when decision-making need to be quick. This discussion demonstrates that questions of subsidiary autonomy are closely connected with the logical structure of system-wide optimisation. It suggests, more generally, that the organisational structure of the MNE can be understood as a rational response to the logical structure of internal problem-solving.

\subsection{Families of decision trees}

The systems view, as its name suggests, comprises a whole family of models of the kind discussed above. Different research questions call for different variants of the model above. Additional markets, production locations and contractual options can all be introduced but there is no point in adding to complexity unless the questions asked demand it. 
The systems view can be expanded into an entire suite of models, each useful for a different purpose. The logical properties of each model will stem from the structure of its decision tree. The decision-tree is a 'fingerprint' of the model, which uniquely identifies each model and highlights its important properties in symbolic form.

By exploring the IB field in a systematic way it is possible, in principle, to identify a list of key questions that the system approach should address. A family of models can then be developed, tailored to the needs of specific questions. In principle there exists an encompassing model, or 'super-model', that includes all of these specific models as special cases. A solution of the super-model permits the solution of each specific model by to be derived from simplifying restrictions imposed on the super-model solution. The development of the super-model requires specialised modelling capabilities. It is an intellectual activity rather than a practitioner activity. To motivate the pursuit of such activity as a route to career advancement, the professional culture of IB studies may need to change.

\section{The industry view}

\subsection{Interactions between firms}

The systems view emphasises the interaction of decisions within a single firm. But many decisions involve interactions between firms. Firms can either compete or cooperate, or combine elements of the two. Competition may stem from direct imitation or the development of new rival technologies, while co-operation may involve mergers or joint ventures. What is really required, therefore, is a systems view of the industry. The systems view of the firm would then be embedded within this wider view.

The systems view of the industry is not merely a view of the industry through the eyes of a firm within it, but rather a detached 'bird's eye' view from the standpoint of the academic or policy-maker. No individual firm is of special interest from this view, unless they possess significant monopoly power.

In IB studies a global industry is usually viewed as an oligopoly, comprising a small number of leading firms and a competitive fringe of smaller firms. The small firms may be recent entrants striving to gain market share, or declining firms pursuing a long-run exit strategy. It is important, however, to recognise the role of licensees, franchisees and subcontractors within this industry view. In the systems view of the firm, set out above, such firms play only a relatively passive role. They compete for contracts with knowledge-intensive firms, but they are not regarded as knowledgeintensive themselves. While they possess local knowledge, they have no monopoly of it, and therefore supply their knowledge on competitive terms. A comprehensive industry view must recognise that these firms may possess knowledge advantages of their own and therefor possess market power.

\subsection{Mapping the structure of an industry}

Both neoclassical theory and early Coasian theory is that they take an industry-level view rather than a firm-level view of the economy. In neoclassical theory production decisions made by other firms interact with consumer demand to determine the 
competitive price to which the firm responds. In Coasian theory each firm is bounded by other firms, and its boundaries are fixed through interaction with these firms.

Neither neoclassical theory nor Coasian theory provides a fully satisfactory account of the industry environment, however. Neoclassical theory typically assumes that there are many small identical perfectly competitive firms. Coasian theory postulates heterogeneous firms operating in imperfect markets, but it rules out proprietary knowledge. A satisfactory account of industry structure must be based on a systems view of the firm as set out above. It would distinguish between production, marketing, R\&D and headquarters. It would also take a modular view of production. It would identify the location and ownership of each facility: the production plants, distribution centres, R\&D laboratories and headquarters offices. These locations would be mapped in relation to major centres of product demand. Flows of products and services would be indicated, including flows of knowledge, semi-processed products, final products, and coordinating information.

Two sets of boundaries would be drawn on the map. The first would be political boundaries identifying different countries. The second would be ownership boundaries, indicating the boundaries between different firms. MNEs would exist where ownership boundaries encompassed political boundaries.

Ownership boundaries would be of two main kinds. Some boundaries would intersect linkages, indicating an arm's length contract between two firms. Boundaries that intersected flows of R\&D would correspond to licensing, subcontracting and franchising arrangements in which an innovative firm supplies knowledge to an ordinary firm possessing relevant local knowledge. Boundaries that intersected flows of semi-processed product flows would correspond to vertical disintegration in multistage production.

Other boundaries would separate firms that had no linkages at all. These firms would typically be competitors, operating rival production systems based on different variants of proprietary knowledge.

\subsection{A systems view of an industry}

The challenge facing theory is then to explain why the map takes the specific form it does. There are many possible configurations, but only one reflects reality at any given time. Theory needs to possess some principle that selected the actual configuration from all the possibilities.

The most significant difference between industry analysis and firm analysis in IB is the requirement in industry analysis to analyse interactions between different knowledge-intensive firms. Some interactions may be negotiated, such as mergers and joint ventures. These involve contractual arrangements that can be analysed using methods similar to those employed above. Competitive interactions, however, do not involve negotiated contracts but mainly rival investments based on conjectures about how rival firms will act and react.

There are two main approaches to modelling interactions of this kind. The first regards interaction as a real-time process and industry outcomes over time, while the 
second regards interaction as a virtual process that results in an equilibrium outcome at a given point in time. The first approach is associated with behavioural models of industry dynamics and the second with the theory of games. Neither approach is entirely satisfactory.

Industry dynamics are usually modelled by postulating simple decision rules followed by firms, and tracking their interactions over time. The results are sensitive to assumed initial conditions, and the sequence in which firms are allowed to move. Sophisticated models incorporate learning, so that decision rules are modified over time. In the long run quick learners tend to profit at the expense of slow learners leading to total dominance by the fastest learners. In practice, however, high speeds of learning are difficult to sustain. Speed of learning is a characteristic of the entrepreneur who heads the firm and takes the key decisions; it is a quality that is difficult to perpetuate through personal succession, or to fully embed in the culture of a firm. Realistic models of industry dynamics need to address the issue of entrepreneurial recruitment, retention and succession, but no model has successfully implemented this approach so far.

The theory of non-co-operative games analyses strategic interactions between rivals. It assumes that interaction is a virtual process in which firms make conjectures about each other's behaviour. There are two main variants: in the first the firms act simultaneously and in the second they act sequentially.

Simultaneous decisions. Firms consider every possible scenario that could result from other firm's behaviours and calculate correctly what their best response would be in each case. Each firm then independently identifies the set of all scenarios in which each firm, including themselves, will respond in the appropriate way given the other firm's behaviours. This is an equilibrium set, in the sense that for any scenario in this set no firm will regret the decision it has made given what it observes that the other firms have done. If there is a single equilibrium scenario there is a unique outcome in which each firm behaves in a definite way. If there is no equilibrium scenario then there is no predicted outcome; if there are several equilibria then it is assumed that one of them will appear, although the logic behind this assumption is unclear.

Sequential decisions. With sequential decision-making each firm acts in turn. Each firm can predict correctly how other firms will react to their decision, and to the decisions already made by other firms. This gives an advantage to the first mover, because through their decision they can influence, within limits, how following firms will react. The sequence must be specified in advance (as in behavioural models). One way of doing this is to assume that the most entrepreneurial firms act first, and the least entrepreneurial last.

From a pragmatic perspective, all three approaches can be used and their predictions compared on a case-by-case basis. In then becomes possible to tinker with the bestperforming theory to improve its fit with the evidence. A useful starting point for analysing industry competition would be IB theories of oligopoly that were developed in the 1970s and have been largely neglected since. For industry co-operation, theories of international joint ventures, firm co-location and agglomeration are an obvious starting point. 


\subsection{Factors influencing the boundaries of firms in a global industry}

Industry analysis can be used to generalise the systems view of the firm set out earlier. An industry outcome, however determined, predicts which firms will innovate and which will not; which firms will serve which national markets, where they will locate headquarters, $R \& D$ and production, whether they will license, subcontract or franchise when serving specific markets. As a bonus, the theory can also predict prices in each market, quantity sold, revenues, costs and profits. If firms innovate with perfect foresight then all firms that innovate will break even or make a profit, and all firms that do not innovate would not have made a profit if that they innovated as well.

In terms of the map discussed above, the solution obtained from the industry analysis identifies all the points and all the boundaries on the map. Industry outcomes can take many different forms, giving many possible configurations of firms. Which configuration prevails at any given time depends, in general, on the state of the global economy and the state of each global industry in particular. Figure 3 identifies some of the major factors influencing industry outcomes. The factors are derived from the discussion in earlier sections of this paper.

The analysis can also be used to compare the different types of configurations that are likely to emerge in different types of global industry (Spender's (1989) 'industry recipes'). It can also explain the nature and direction of these changes. Changes in exogenous factors in the industry environment will induce endogenous changes in firm behaviour, thereby re-drawing the boundaries between firms as they adapt to new industry conditions. Competitive forces may stimulate entry and exit, thereby changing the population of firms as a whole.

Systems theory applied to IB theory is not a theory of any particular type of MNE. 'US', 'European', Chinese' and 'emerging market' MNEs simply represent different outcomes of industry interaction, conditioned by the industry environment prevailing at any given time. It is a general theory, as noted above, and it is unnecessary to develop special theories every time circumstances change.

\section{Multi-level analysis}

The range of topics encompassed by modern IB studies is impressive but their sheer diversity raises the question of how they are related. The usual answer is that they focus on different functional areas of the firm, and employ different methods of analysis, but are united by a focus on international issues. The theory set out above suggests another way of categorising the literature, however, namely by level of analysis.

Table 4 identifies five levels of analysis commonly found in IB studies. Higher levels of analysis typically involve greater aggregation. The preceding analysis is embedded in the middle level levels of this analysis, which means that there is an opportunity to both raise and lower the level of analysis. The table indicates what this would mean in practice.

- The highest level of analysis relates to the global economy. It concerns patterns of trade flow, FDI flow and knowledge flow between major countries. It features trading blocs and international institutions. 
- The next level disaggregates the global economy into global industries. Although certain industries predominate in IB literature - automobiles, pharmaceuticals, computers, textile, etc. - this level includes all major sectors including many different types of services.

- Global industries comprise a large collection of firms, including MNEs, their partners (licensees, franchisees, subcontractors, etc.) their rivals, joint venture partners and so on; they also include many small firms of a purely national character. Firm-level studies typically focus on innovation strategies and headquarters-subsidiary relations. The interface between the firm level and the industry level is a key issue in IB theory, as noted above.

- The modular view of the firm identifies different types of activity carried out in different types of establishments - production plants, wholesale warehouses, retail outlets, R\&D laboratories and so on. These specialised activities, and the establishments in which they are carried out, can be examined separately. This creates specialised sub-fields, such as international marketing and innovation management. Modularisation may extend to the sub-division of plants in multi-stage production and multi-tier supply chains; this is linked to supply chain management. Modularisation may also be applied to administrative activities. Headquarters may comprise separate legal, financial, and strategy departments. In some cases headquarters may be distributed across a network of different locations, with legal located in a tax haven, financial close to a major stock market and strategic at a global communications hub. The internal coordination of specialised establishment focused on specific functional areas creates another level of analysis. While firm-level analysis typically focuses on inter-plant coordination within a multi-plant firm, this level of analysis focuses on intra-plant coordination instead.

- The lowest level of analysis, corresponding to the highest level of disaggregation, focuses on individual people. These are typically employees usually managers, but sometimes workers too. The selection, training and retention of key employees are crucial to the success of the firm. Yet this level of analysis is often detached from mainstream IB research and treated separately as international human resource management. Furthermore, it is often forgotten that many key decisions in a firm are taken by entrepreneurs people who specialise in taking judgemental decisions involve the commitment of large resources under conditions of great uncertainty. People matter not only because the strategies of a firm impact on many people customers, suppliers and shareholders as well as employees. People matter because it is people that take the key decisions that determine strategy. The firm is an institution - a legal construct - and does not have a mind of its own. The minds that determine strategies are the minds of individual entrepreneurs, such as the founder, CEO or principal personal shareholder of the firm.

A key component of the research agenda for economic modelling in IB is to extend the previous theory to other levels of analysis. Extending upwards will allow the theory to inform debates about the future of the global economy. IB scholarship is often marginalised in policy debates about global futures because its high-level theory is under-developed, and extending the system view to this level would help to resolve this problem. Extending downwards to the individual level would emphasise the role of personal characteristics in firm performance, and counter a tendency in current 
literature to assume that firms and not people are the principal actors in IB. It would also advance understanding of the role of teamwork in coordinating individual action within the firm.

\section{Conclusion}

This paper has set out an agenda for economic modelling in IB. Economic modelling provides a degree of relevance and intellectual rigour that other forms of theorising cannot match. MNEs are fundamentally economic organisations, allocating scarce resources internally in order to compete against rival firms. They are complex organisations operating in a complex environment, and formal models are therefore required to clarify the inter-dependencies within and between firms.

Good models are based on a small set of explicit assumptions from which a range of distinct but related hypotheses can be derived. The logic of such models can often be expressed most easily in mathematical terms. Mathematics is a language like any other; many IB scholars have mastered multiple languages, and it would be highly advantageous if they mastered mathematics too.

Standard economic models are typical based on neoclassical assumptions. IB models require that some neoclassical assumptions - perfect markets and free knowledge are replaced by weaker assumptions - namely market imperfections and proprietary knowledge. Confusion between plants and firms must also be resolved: plants produce, firms coordinate, and the same firm can coordinate several plants. In a spatially distributed politically divided world, multi-plant coordination creates the MNE.

Formal modelling must be based on secure foundations, and these foundations are provided by early IB theory. Later theory is too simplistic and wedded to a 'boardroom view' of the firm. Classic internalisation theory was established in the 1970 s and extended in the 1990s by the 'systems view'. Since then the pace of theoretical development has slowed, but there is now an opportunity to revive it, particularly as new economic methods, such as game theory, have become available. The systems view can be extended to the industry level, and additional levels of analysis can also be explored. By employing the same small set of assumptions at all levels of analysis, a coherent theory of IB will emerge that encompasses the many different fields covered by existing IB literature. 


\section{References}

Alchian, Armen A. and Harold Demsetz (1972) Production, information costs and economic organization, American Economic Review, 72, 777-795

Arrow, Kennneth J. (1975) Vertical integration and communication. Bell Journal of Economics, 5, 73-183.

Buckley, Peter J. and Mark Casson (1976) The Future of the Multinational Enterprise, London: Macmillan

Buckley, Peter J. and Mark Casson (1998a) Analyzing foreign market entry strategies: Extending the internalization approach, Journal of International Business Studies, 29 (3), 539-562.

Buckley, Peter J. and Mark Casson (1998b) Models of the multinational enterprise, Journal of International Business Studies, 29 (1), 21-44.

Casson, Mark (1979) Alternatives to the Multinational Enterprise, London: Macmillan

Casson, Mark (1985) Multinational monopolies and international cartels in Peter J. Buckley and Mark Casson, The Economic Theory of the Multinational Enterprise, London: Macmillan, Chapter 4, 60-76.

Casson, Mark (1987) Quality control and vertical integration, in Mark Casson, The Firm and the Market, Cambridge, MA: MIT Press, Chapter 4, 84-120

Casson, Mark (2014) Coase and international business: the origin and development of internalisation theory, Managerial and Decision Economics, 36 (1), 55-66

Casson, Mark (2016) The Theory of International Business: Economic Models and Methods, Switzerland: Palgrave Macmillan

Casson, Mark (2016) Alan Rugman's methodology, International Business Review, 25 (3), 758-766.

Casson, Mark, Porter, Lynda, and Wadeson, Nigel (2016) Internalization theory: an unfinished agenda. International Business Review, 25 (6), 1223-1234

Casson, Mark. (2014) The economic theory of the firm as a foundation for international business theory, Multinational Business Review, 22 (3), 205-226

Casson, Mark, Geoffrey Jones and Teresa da Silva Lopes (2017) Explaining the Unconventional, Paper, presented at the Academy of International Business (UK Chapter) / Dunning Centre Conference, University of Reading, April 3-5.

Cheung, Stephen N.S. (1969) Transaction costs, risk aversion and the choice of contractual arrangements, Journal of Law and Economics, 12, 23-42. 
Coase, Ronald H.(1937) The nature of the firm, Economica (new series), 4, 387-405

Demsetz, Harold (1968) The costs of contracting, Quarterly Journal of Economics, $82,33-53$

Dunning, John H. (1958) American Investment in British Manufacturing Industry, London: Allen \& Unwin

Dunning, John H. (1977) Trade, location of economic activity and the MNE: the search for an eclectic approach, in Bertil Ohlin, P-O. Hesselborn and P.M.Wijkman (eds.) The International Allocation of Economic Activity, London: Macmillan

Hymer, Stephen H. (1976) The International Operations of National Firms: A Study of Direct Investment, Cambridge, MA: MIT Press, PhD dissertation, MIT, 1960.

Kemp, Murray C. (1971) The Pure Theory of International Trade and Investment, Englewood Cliffs, NJ: Prentice-Hall

Kindleberger, Charles (1969) American Business Abroad, New Haven: Yale University Press

Klein, Benjamin, R.G. Crawford and Armen A. Alchian (1978) Vertical integration, appropriable rents and the competitive contracting process, Journal of Law and Economics, 21, 297-326.

MacDougall, G.D.A. (1960) The benefits and costs of private investment from abroad, Economic Record, 36, 13-35

Morgan, Mary S. (2012) The World in a Model: How Economists Work and Think, Cambridge: Cambridge University Press

Porter, Michael E. (1980) Competitive Strategy, New York: Free Press

Spender, J.-C. (1989) Industry Recipes, Oxford: Blackwell

Vaitsos, Constantine (1974) Inter-country Income Distribution and Transnational Enterprises, Oxford: Oxford University Press

Warren-Boulton, F.R. (1978) Vertical Integration of Markets: Business and Labour Practices, Cambridge, Mass: Ballinger

Williamson, Oliver E. (1975) Markets and Hierarchies: Analysis and Anti-trust Considerations, Mew York: Free Press

Williamson, Oliver E. (1985) The Economic Institutions of Capitalism, New York: Free Press 
Table 1: Four key characteristics of post-1945: a comparison of neoclassical and IB explanations

Evidence

Direction of net flow:

Investment flows mainly from

US to UK

'Cross-hauling': There is also some UK investment in the US-often in the same industries

Industrial bias. Flows are concentrated in specific industries
Neoclassical prediction

Investment flows from lowprofit countries to high-profit countries

Cross-investment is inefficient perfect international capital markets make and impossible

Time profile. Gross investment flows increase steadily

Flows affects all industries equally, unless there are industry-specific government barriers
Investment flows are intermittent. They are once-for all stock adjustments.

\section{IB theory explanation}

US firms make high [monopoly] profits from proprietary technology. Most UK competitors do not possess such technology

UK high-technology firms can invest in the US for the same reasons that US firms invest in the UK. It is efficient to share technologies wherever they are developed.

Direct (majority equity) investment is different to indirect (portfolio) because it confers control. Control is required mainly to protect knowledge transfer, which is highest in technology- and marketing-intensive industries.

The flow of direct investment increases as technological innovation and brand innovation increase. 
Table 2: Three key questions addressed by early IB theory

Question

Why did US firms locate production in the UK?

How could they compete against UK firms with better local knowledge?

Why did they not sell (license) theory advantage to UK firms?
Answer

Relevant economic theory

'Location advantage': jump Classical theories of tariff barriers, eliminate location and trade transport costs, cheaper labour (Ricardian comparative advantage); economic geography (the interplay of transport costs and economics of scale)

'Ownership advantage': $\quad$ Monopoly and oligopoly they had a compensating theory advantage which could be transferred internationally: proprietary knowledge

'Internalisation advantage': Institutions avoiding costs of arm's (coordination/transaction length contracts due, e.g., to costs) and knowledge weak intellectual property (public good) rights (IPR) 
Table 3: The theory of vertical integration: potential coordination failures in an intermediate product market linking upstream and downstream production activities

\begin{tabular}{|l|l|}
\hline Authors & Problem to which internalisation may be the answer \\
\hline Various & $\begin{array}{l}\text { Duplication of inventory due to distrust between managers } \\
\text { of different plants }\end{array}$ \\
\hline Arrow & $\begin{array}{l}\text { Missing contingent forward contracts in intermediate } \\
\text { product markets inhibit inter-temporal coordination }\end{array}$ \\
\hline $\begin{array}{l}\text { Warren-Boulton and } \\
\text { others }\end{array}$ & $\begin{array}{l}\text { Economies of scale within multi-stage production generate } \\
\text { monopoly/monopsony power which distorts intermediate } \\
\text { product prices and hence factor-proportions at earlier } \\
\text { and/or later stages of production }\end{array}$ \\
\hline Williamson Mark I & $\begin{array}{l}\text { Recurrent high-frequency contracts for intermediate } \\
\text { product are costly to negotiate and enforce. }\end{array}$ \\
\hline Casson & $\begin{array}{l}\text { Quality control is difficult for a downstream buyer when } \\
\text { the intermediate product is an 'experience' rather than } \\
\text { 'inspection' good. }\end{array}$ \\
\hline $\begin{array}{l}\text { Williamson Mark II/ } \\
\text { Klein Crawford \& } \\
\text { Alchian }\end{array}$ & $\begin{array}{l}\text { High sunk costs and bilateral lock-in within multi-stage } \\
\text { production create 'small-numbers' bargaining problems } \\
\text { between 'opportunistic' upstream and downstream plants }\end{array}$ \\
\hline
\end{tabular}


Table 4: Levels of analysis

\begin{tabular}{|l|l|l|}
\hline Level & Type & Description \\
\hline $\mathbf{1}$ & Global Economy & $\begin{array}{l}\text { Structural change driven by basic research, shrinking } \\
\text { distance, environmental change, etc. }\end{array}$ \\
\hline $\mathbf{2}$ & Global industry & Inter-firm competition and co-operation \\
\hline $\mathbf{3}$ & Firm & $\begin{array}{l}\text { Boundaries of the firm; interaction of ownership } \\
\text { and location on production, marketing, R\&D and } \\
\text { headquarters }\end{array}$ \\
\hline $\mathbf{4}$ & Plant and office & $\begin{array}{l}\text { Intra-plant organisation, management procedures } \\
\text { and working practices }\end{array}$ \\
\hline $\mathbf{5}$ & Personal & $\begin{array}{l}\text { Recruitment, retention and motivation of staff; } \\
\text { personal relations with customers and suppliers }\end{array}$ \\
\hline
\end{tabular}


Figure 1

Interaction of production, marketing and R\&D: Potential inter-modular linkages involving flows of intermediate products

Key: Box: physical activity; Triangle: generating knowledge; Circle: generating local information. Lines: Black: product; Dark grey: knowledge; Light grey: information. Arrows: Direction of principal flow

$\mathrm{R} \& \mathrm{D}$

Upstream production

Downstream production/ Marketing and distribution

Customer

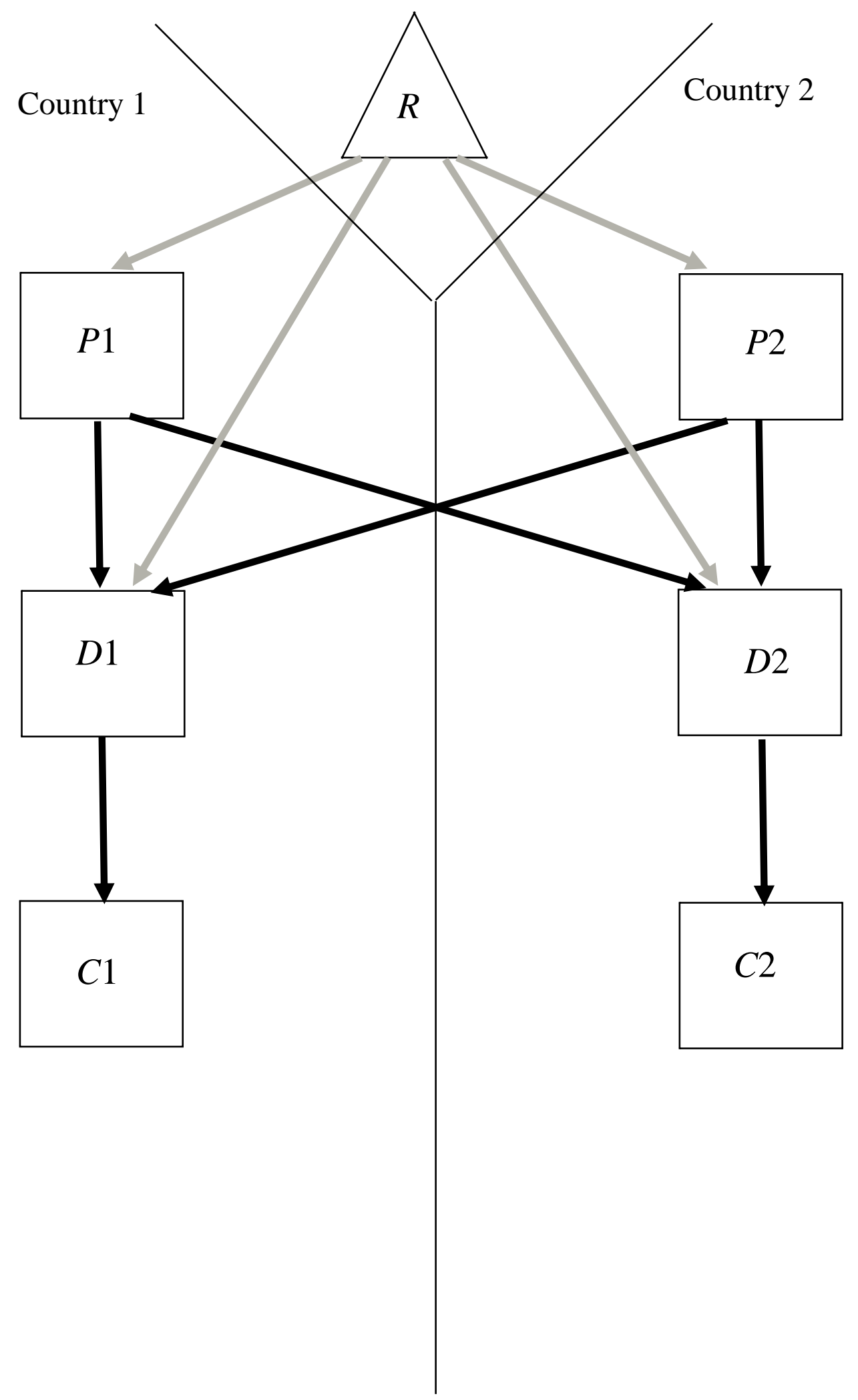


Figure 2

Decision tree for solution of system optimisation

$\mathrm{R} \& \mathrm{D}$ decision

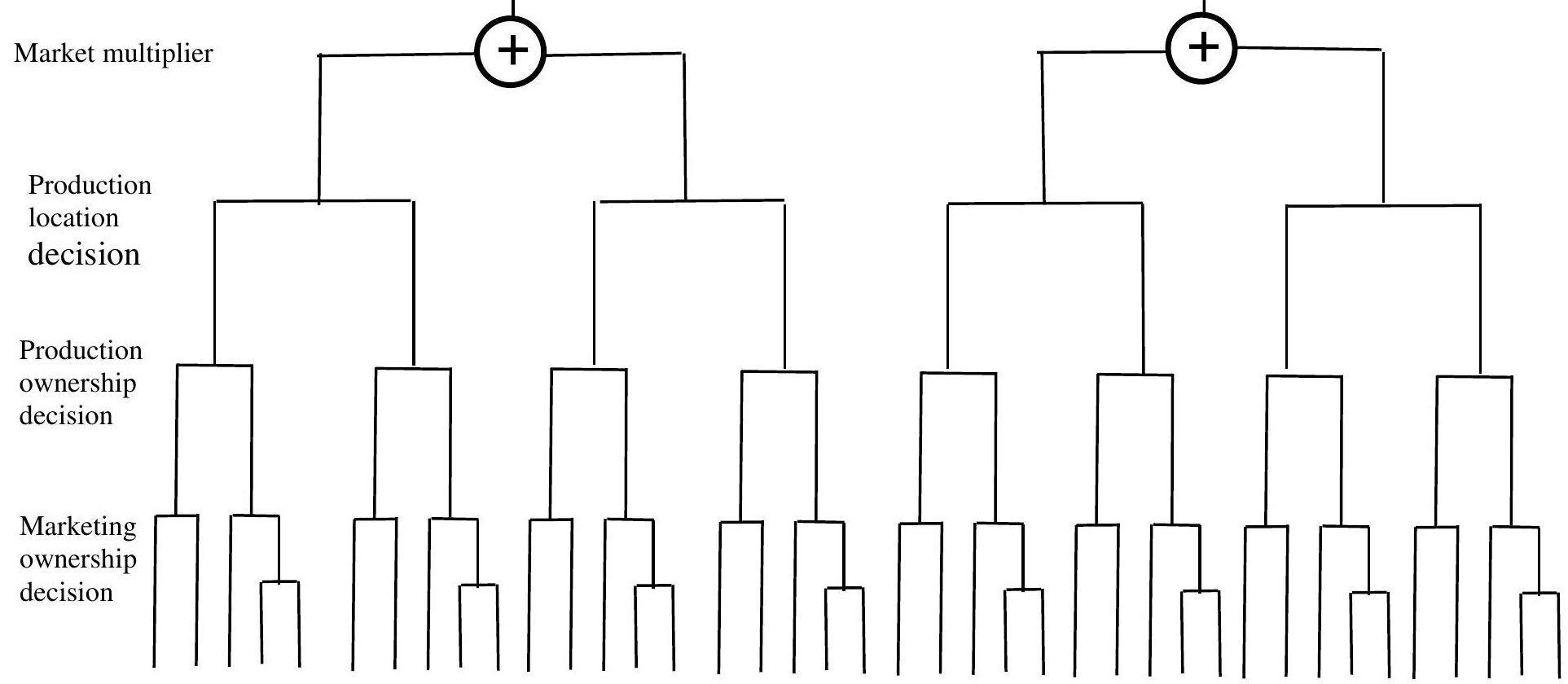




\begin{tabular}{|c|c|c|c|c|c|c|c|}
\hline \multicolumn{4}{|c|}{ R\&D location 1} & \multicolumn{4}{|c|}{ R\&D location 2} \\
\hline \multicolumn{2}{|c|}{ Supply market 1} & \multicolumn{2}{|c|}{ Supply market 2} & \multicolumn{2}{|c|}{ Supply market 1} & \multicolumn{2}{|c|}{ Supply market 2} \\
\hline $\begin{array}{c}\text { Production } \\
\text { in location } \\
1\end{array}$ & $\begin{array}{c}\text { Production } \\
\text { in location } \\
2\end{array}$ & $\begin{array}{c}\text { Production } \\
\text { in location } \\
1\end{array}$ & $\begin{array}{c}\text { Production } \\
\text { in location } \\
2\end{array}$ & $\begin{array}{c}\text { Production } \\
\text { in location } \\
1\end{array}$ & $\begin{array}{c}\text { Production } \\
\text { in location } \\
2\end{array}$ & $\begin{array}{c}\text { Production } \\
\text { in location } \\
1\end{array}$ & $\begin{array}{c}\text { Production } \\
\text { in location } \\
2\end{array}$ \\
\hline \multicolumn{8}{|c|}{$\begin{array}{l}\text { Production and marketing ownership decisions: Left to right } \\
\text { Full internalisation (FDI); Franchising; Subcontracting; Licensing to a single integrated licensee; } \\
\text { 'Putting out': subcontracting and franchising to separate firms }\end{array}$} \\
\hline
\end{tabular}


Figure 3: Factors in the industry environment

General factors

Global geographical fundamentals:

coastlines, rivers, altitudes, climates, soils, etc.

Environmental legacy of human activity:

- Positive: infrastructure investment in transport, communications, urban utilities)

- Negative: mining, pollution, climate change, species extinction, etc.
Specific factors appearing in the industry model

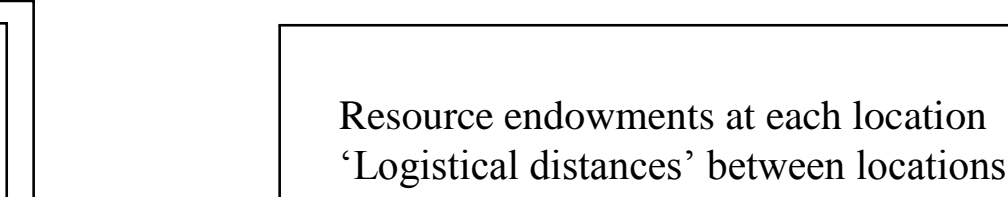

Cultural legacy of human activity:

Scientific knowledge base (technology)

Morality and law (property rights)

Languages

Political institutions (nation state)

Political

process

Policy formation in individual nations

Dominant nation (imperialist) decides

policies:

War or peace

Autocracy or democracy

Property rights are weak or strong

Protection or free trade

High tax/low tax

State of technological know-how Education and skills at each location (labour productivity, managerial competence)

Costs of communication between locations

Degrees of trust between locations
Tariffs and taxes

Local tastes and preferences Local costs of enforcement

'Political distances' between nations 
